\title{
The Dynamics of Flow Discharge and Suspension Flow Discharge in Volcano Watershed with Agroforestry Land Cover
}

\author{
La Ode Hadini $^{1}$, Junun Sartohadi ${ }^{2}$, M. Anggri Setiawan ${ }^{3}$, Djati Mardiatno ${ }^{3}$ \\ ${ }^{1}$ Faculty of Earth Sciences and Technology, Universitas Halu Oleo, Kendari 93132 \\ ${ }^{2}$ Faculty of Agriculture, Universitas Gadjah Mada, Yogyakarta 55281 \\ ${ }^{3}$ Faculty of Geography, Universitas Gadjah Mada, Yogyakarta 55281 \\ hadini74@gmail.com
}

Received 12-01-2021; accepted 27-06-2021

\begin{abstract}
The suspension flows the upper part of a volcano watershed, which has a very thick soil condition, is sensitive to land use. Agroforestry is the dominant land use in the volcanic landscape of Indonesia. This research, performed in the agroforestry area, covered the characteristics of the correspondence between flow discharge and suspension discharge during the flow. The suspension flow was measured at the outlet of key watershed areas, which yielded 436 suspension data. The measurement analysis was conducted at every rain event in the field and the laboratory. The crop characteristics in the catchment area were recorded in detail during the field survey. The characteristics of the channels converging toward the gully system were observed during the field survey. There were the relationship patterns between the peak flow discharge and the suspension discharge with the average time interval between the rain events, and the occurrence of suspension flow was 17.7 minutes, and the peak suspension content varied with an average of $1.03 \mathrm{~g} / \mathrm{L}$; then the grain size of the suspension was dominated by clay fraction with an average of $73 \%$ at the rising stage and average of $69 \%$ the falling stage.
\end{abstract}

Keywords: Agroforestry, Discharge, Suspension, Volcano, Watershed.

\section{Introduction}

The land use pattern in volcanic lands in Indonesia is distinctive. Indonesia has more than 400 volcanoes, 127 of which are included in the active category [1]. The order of a volcanic landscape starts from the cone, the upper slope - the foot slope. This landscape's typical land use pattern is the nonintensive utilization of cone and upper slope due to high-intensity volcanic hazards [2]. Production activities in the form of agroforestry have recently appeared in the middle slope [3]. Agricultural land usually occupies areas from the foot slope [4].

The suspension flow from the upper part of a volcanic watershed with very thick soil conditions is sensitive to land utilization. The suspension flow dynamics illustrate the flow response to the dynamics

Cite this as: Hadini, L.O., Sartohadi, J. \&Setiawan, M.A., Mardiatno, D. (2021). The Dynamics of Flow Discharge and Suspension Flow Discharge in Volcano Watershed with Agroforestry Land Cover. Civil and Environmental Science Journal (Civense), 4(2), 141-153. doi: https://doi.org/10.21776/ub.civense.2021.00402.4 
of the watershed characteristics, one of which is the land use pattern. The suspension flow dynamics are essential to identify the watershed criticality qualitatively. This approach, however, requires further development to achieve time and cost-effectiveness, and efficiency [5][6][7]. The suspension flow is strongly related to soil loss rate and soil fertility deterioration process. It also triggers deposition and sedimentation, which lead to siltation [8][9][10][11].

The dynamics of the suspension flow characteristics and the change in watershed conditions are observable during certain rainfall events. The relationship between these two dynamics is explainable through suspension hydrograph analysis. In a hydrograph, flow discharge and suspension discharge parameters depict the aforementioned dynamics [12][13][14][15][16][17][18][19]. These dynamics are associated with the balance system between rainfall as the input, infiltration, and soil water storage in a watershed area [18][20][21][22][23]. The suspension flow dynamics presented in the suspension hydrograph's response demonstrate any changes in rain input, infiltration, and soil water storage.

The studies of flow suspension dynamics under the land use of agroforestry have been reported to be optimal enough to control the formation of suspension flow [18][24][25][26][27][28]. However, they do not deal with the physical characteristics of watersheds and landscapes covered with homogeneous agroforestry as crucial watershed areas. Furthermore, the studies of flow and suspension flow dynamics in volcanic watersheds have so far taken place in watershed areas with varied land use patterns along with other geophysical conditions that involve many assumptions or generalizations. Therefore, the results of studies based on this assumption generalization pose a potential bias toward the real states in the field.

This research aims to involve a key area approach particularly for a watershed with small area coverage and homogeneous agroforestry and geophysical conditions. This approach enables planning the watershed's physical characteristics in a more detailed and uniform manner to create a study that approximates the actual conditions in the field. Also, it can make a study applicable to volcanic watersheds with similar characteristics. The study of flow suspension dynamics in volcanic watersheds with agroforestry covers the following problems: the corresponding responses of flow and suspension, the time lag between rain events and the initial formation of suspension flow, and the grain size of the suspension during the flow.

\section{Material and Methods}

This study used a key area method. With a large area of $\pm 300 \mathrm{ha}\left(0.03 \mathrm{~km}^{2}\right)$, Bompon Watershed was designated as the key area because its land utilization was agroforestry, mainly in the volcanic foot slope area. It is a volcanic watershed on the borders of Magelang Regency, Purworejo Regency, and Wonosobo Regency, Central Java (Figure 1). It lies between $9163200 \mathrm{mN}-916400 \mathrm{mN}$ and 396300 $\mathrm{mE}-397800 \mathrm{mE}$ with an elevation between 377 and $539 \mathrm{~m}$ above sea level. Unevenly distributed rainfall with an annual average of 2,214.5 mm typifies its climatic characteristics. Bompon Watershed is located in the transition zone between the material deposition zones of the Tertiary and Quaternary Volcanoes on the foot slope of Sumbing Volcano. It experiences a volcanic intrusion that causes an intensive alteration process on the bedrocks. The intensive alteration and weathering processes result in a soil layer with a thickness of over 10 meters, which is categorized as super thick soil [24][25][26][27][28][29]. The vegetation cover is in the form of agroforestry, i.e., land use with diverse plant types like durian, coconut, green cottonwood, mahogany, Albizia chinensis, rosewood, Gnetum gnemon, Lansium dookoo, Lansium domesticum cv. Kokossan, jackfruit, bamboo, banana, Salacca zalacca, turmeric, Javanese turmeric, and cardamom. At the base of the tree stands, there are plants attached to the ground surface, namely grass and aromatic ginger. The vegetation cover is dense (478.78 trees $/ \mathrm{m}^{2}$ ), with a wide canopy spanning between 1-12 meters. The height variation of the vegetation stands forms a plant layering structure (multilayer canopy).

The study used a key area method, which was carried out by measuring the suspension flow at the gully outlet; this measurement produced 436 suspension data. The suspension flow was measured at every rain event in the field and in the laboratory. The characteristics of the crop in the rain catchment area were recorded in detail during the field survey. In addition, the characteristics of the channels 
converging toward the gully system were observed in the field survey. These data were presented in tables and graphs (suspension hydrograph) to describe the causal relationship between rain phenomena and suspension flows.

The suspension flow analysis was built based on rainfall and water level data. The rainfall data included the dynamics of rain depth, intensity, and duration at the initial formation of the suspension flow. The suspension was analyzed using the filtration method, which produced suspension weight and concentration data. The suspension discharge was obtained by multiplying the concentration of the suspensions by flow discharge, as Strand (1982) proposed in [30]. The flow discharge obtained for each water level observed at the outlet of a stream gauge with broad-crested weir was calculated using the Weir discharge equation [31].

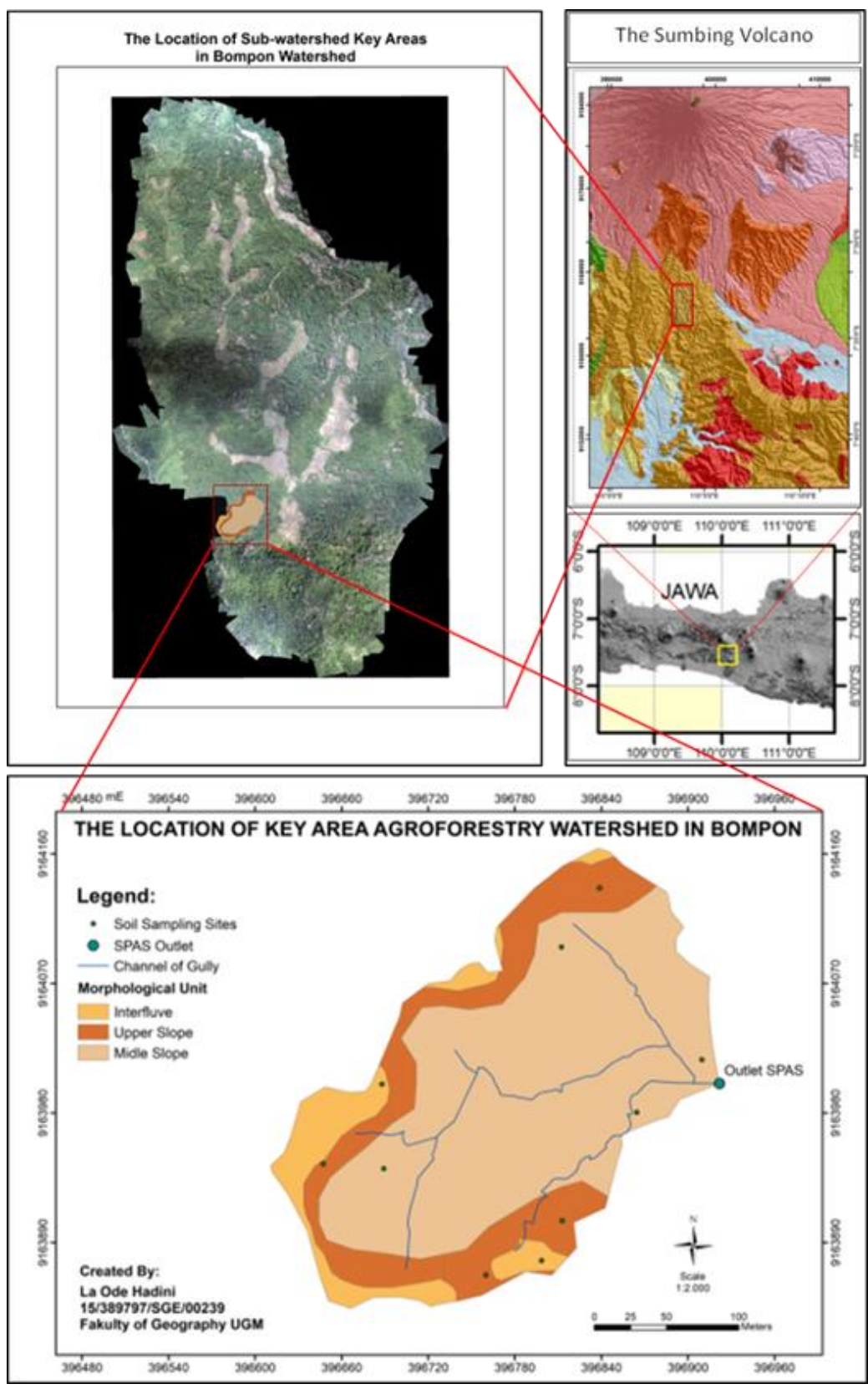

Figure 1. The Location of Key Areas in the Study Site and the Geomorphological Unit Conditions in Bompon Watershed. 


\section{Result and Discussion}

\subsection{The correspondence pattern between flow discharge and suspension discharge}

During the rain events, the dynamics of the suspension flow showed correspondence patterns between flow discharge and suspension discharge in the rising and falling phases. At the rising stage, an increase in flow discharge was accompanied by a rise in the suspension discharge and vice versa, a decrease in flow discharge was followed by a decline in the suspension discharge (Figure 2). At the peak condition, three correspondence patterns between the flow discharge and the suspension discharge were identified. Namely, (1) the peak flow discharge corresponded to the peak suspension discharge, (2) the peak flow discharge preceded the peak suspension discharge, and (2) the peak flow discharge occurred after the peak suspension discharge.

Table 1. The suspension conditions during the flows in each rain event

\begin{tabular}{|c|c|c|c|c|c|c|c|}
\hline No & Rain events & Number of data & $\begin{array}{l}\text { Rain intensity } \\
\text { (mm/hour) }\end{array}$ & $\begin{array}{c}\text { Peak } \\
\text { suspension } \\
\text { concentration } \\
\mathrm{Cp} \\
(\mathrm{g} / \mathrm{L}) \\
\end{array}$ & $\begin{array}{c}\text { Peak runoff } \\
\text { discharge Qp } \\
(\mathrm{L} / \mathrm{s})\end{array}$ & $\begin{array}{c}\text { Peak } \\
\text { suspension } \\
\text { discharge Qsp } \\
(\mathrm{g} / \mathrm{s})\end{array}$ & $\begin{array}{c}\text { Type } \\
\text { tQp and } \\
\text { tQsp }\end{array}$ \\
\hline 1 & 2 & 3 & & 5 & 6 & 7 & 11 \\
\hline 1 & 18 February 2017 & 4 & 8.94 & 0.0711 & 13.2745 & 0.9432 & $\mathrm{tQp}=\mathrm{tQsp}$ \\
\hline 2 & 20 February 2017 & 10 & 8.88 & 0.2989 & 14.3273 & 4.2820 & tQp $>$ tQsp \\
\hline 3 & 21 February 2017-1 & 7 & 5.14 & 0.0016 & 8.4806 & 0.0136 & $\mathrm{tQp}<\mathrm{tQsp}$ \\
\hline 4 & 21 February 2017-2 & 9 & 4.44 & 0.0259 & 8.4806 & 0.2197 & $\mathrm{tQp}=\mathrm{tQsp}$ \\
\hline 5 & 22 February 2017 & 6 & 6.86 & 0.0252 & 8.0463 & 0.2025 & $\mathrm{tQp}<\mathrm{tQsp}$ \\
\hline 6 & 23 February 2017 & 2 & 1.80 & 0.0081 & 7.2035 & 0.0586 & $\mathrm{tQp}=\mathrm{tQsp}$ \\
\hline 7 & 25 February 2017 & 28 & 10.71 & 0.9894 & 28.4727 & 28.1720 & $\mathrm{tQp}=\mathrm{tQsp}$ \\
\hline 8 & 27 February 2017 & 2 & 4.40 & 0.0147 & 7.2035 & 0.1057 & $\mathrm{tQp}=\mathrm{tQsp}$ \\
\hline 9 & 28 February 2017 & 25 & 19.55 & 2.3453 & 43.5071 & 102.0355 & $\mathrm{tQp}=\mathrm{tQsp}$ \\
\hline 10 & 01 March 2017 & 2 & 6.60 & 0.1560 & 8.4806 & 1.3230 & $\mathrm{tQp}=\mathrm{tQsp}$ \\
\hline 11 & 01 March 2017-2 & 31 & 29.25 & 3.0703 & 129.9952 & 399.1225 & $\mathrm{tQp}=\mathrm{tQsp}$ \\
\hline 12 & 02 March 2017 & 34 & 22.34 & 1.9138 & 106.7442 & 204.2839 & $\mathrm{tQp}=\mathrm{tQsp}$ \\
\hline 13 & 05 March 2017 & 13 & 12.74 & 0.5655 & 39.5293 & 1.9314 & tQp $>$ tQsp \\
\hline 14 & 07 March 2017 & 11 & 27.16 & 0.3209 & 25.0950 & 8.0522 & $\mathrm{tQp}>\mathrm{tQsp}$ \\
\hline 15 & 18 March 2017 & 15 & 25.34 & 0.6623 & 18.8337 & 12.4739 & $\mathrm{tQp}=\mathrm{tQsp}$ \\
\hline 16 & 25 March 2017 & 10 & 16.80 & 0.9541 & 18.8337 & 17.9699 & $\mathrm{tQp}=\mathrm{tQsp}$ \\
\hline 17 & 26 March 2017 & 28 & 36.39 & 2.8932 & 142.2171 & 411.4681 & $\mathrm{tQp}=\mathrm{tQsp}$ \\
\hline 18 & 5 April 2017 & 39 & 75.08 & 2.7803 & 316.0675 & 878.7592 & $\mathrm{tQp}<\mathrm{tQsp}$ \\
\hline 19 & 6 April 2017 & 23 & 26.45 & 0.8329 & 118.1667 & 98.4224 & $\mathrm{tQp}<\mathrm{tQsp}$ \\
\hline 20 & 18 April 2017 & 13 & 29.18 & 0.9152 & 32.0076 & 29.2937 & $\mathrm{tQp}=\mathrm{tQsp}$ \\
\hline 21 & 19 January 2018 & 3 & 10.58 & 0.1120 & 10.7772 & 1.2066 & $\mathrm{tQp}<\mathrm{tQsp}$ \\
\hline 22 & 20 January 2018 & 7 & 3.45 & 0.8137 & 11.7526 & 9.5627 & $\mathrm{tQp}=\mathrm{tQsp}$ \\
\hline 23 & 21 January 2018 & 9 & 5.64 & 0.1742 & 8.4806 & 1.4773 & tQp $>$ tQsp \\
\hline 24 & 23 January 2018 & 2 & 4.60 & 0.2566 & 6.3958 & 1.6410 & $\mathrm{tQp}=\mathrm{tQsp}$ \\
\hline 25 & 24 January 2018-1 & 5 & 1.80 & 0.1519 & 10.7772 & 1.6368 & tQp $>$ tQsp \\
\hline 26 & 24 January 2018-2 & 21 & 9.60 & 2.1257 & 65.4142 & 139.0481 & $\mathrm{tQp}=\mathrm{tQsp}$ \\
\hline 27 & 24 January 2018-3 & 4 & 2.52 & 0.2945 & 10.7772 & 3.1741 & $\mathrm{tQp}=\mathrm{tQsp}$ \\
\hline 28 & 24 January 2018-4 & 4 & 3.84 & 0.2765 & 10.7772 & 2.9798 & $\mathrm{tQp}<\mathrm{tQsp}$ \\
\hline 29 & 26 January 2018 & 3 & 3.75 & 0.0553 & 14.3273 & 0.7918 & $\mathrm{tQp}>\mathrm{tQsp}$ \\
\hline 30 & 29 January 2018 & 3 & 7.80 & 0.1513 & 9.3745 & 1.4187 & $\mathrm{tQp}=\mathrm{tQsp}$ \\
\hline 31 & 31 January 2018-1 & 5 & 21.42 & 0.6379 & 8.4806 & 5.4094 & $\mathrm{tQp}=\mathrm{tQsp}$ \\
\hline 32 & 31 January 2018-2 & 6 & 16.80 & 0.1665 & 8.4806 & 1.4118 & $\mathrm{tQp}<\mathrm{tQsp}$ \\
\hline 33 & 1 February 2018 & 7 & 22.14 & 1.2545 & 14.8651 & 18.6486 & $\mathrm{tQp}=\mathrm{tQsp}$ \\
\hline 34 & 4 February 2018-1 & 5 & 20.88 & 0.7136 & 11.2610 & 8.0355 & $\mathrm{tQp}=\mathrm{tQsp}$ \\
\hline 35 & 4 February 2018-2 & 14 & 17.28 & 1.1217 & 51.8768 & 58.1903 & $\mathrm{tQp}<\mathrm{tQsp}$ \\
\hline 36 & 08 February 2018 & 5 & 12.48 & 4.7086 & 21.2571 & 100.0904 & $\mathrm{tQp}=\mathrm{tQsp}$ \\
\hline 37 & 13 Februri 2018 & 21 & 45.12 & 2.7227 & 115.8493 & 315.4219 & $\mathrm{tQp}=\mathrm{tQsp}$ \\
\hline 38 & 23 February 2018 & 12 & 38.40 & 0.9552 & 47.6241 & 45.4924 & $\mathrm{tQp}>\mathrm{tQsp}$ \\
\hline 39 & 24 February 2018 & 5 & 16.56 & 0.8113 & 13.2745 & 10.7700 & $\mathrm{tQp}=\mathrm{tQsp}$ \\
\hline 40 & 07 March 2018 & 11 & 15.10 & 2.2446 & 32.0076 & 71.8442 & $\mathrm{tQp}=\mathrm{tQsp}$ \\
\hline \multirow[t]{5}{*}{41} & 08 March 2018 & 16 & 49.69 & 3.7600 & 106.7442 & 401.3581 & $\mathrm{tQp}=\mathrm{tQsp}$ \\
\hline & Total & 480 & & & & & \\
\hline & Min. & 2 & 1.80 & 0.0016 & 6.3958 & 0.0136 & 0.4500 \\
\hline & Mean & 12 & 17.26 & 1.0330 & 41.1108 & 82.8962 & 4.31 \\
\hline & Max. & 39 & 75.08 & 4.7086 & 316.0675 & 878.7592 & 18.7692 \\
\hline
\end{tabular}


In general, the peak conditions showed a corresponding pattern between the peak flow discharge and the peak suspension discharge. Out of the 41 rain events observed in the field, (1) the peak flow discharge corresponded to the peak suspension discharge in 26 events, (2) the peak flow discharge preceded the peak suspension discharge in 7 events, and (3) the peak flow discharge occurred after the peak suspension discharge in 8 events (Table 1).

The flow discharge condition substantially affects the suspension discharge; therefore, it determines the correspondence shape patterns generated by the peak flow discharge and the peak suspension discharge. The influence of flow discharge on suspension discharge is as reported in [32] [33] and [34]. The dynamics of runoff discharge are part of the balance system between the dynamics of rain input, infiltration capacity, and soil water storage [13]. The rain input triggers the formation of suspension flow that follows the dynamics of flow (runoff) formation when infiltration capacity and soil water storage are exceeded [12][14][15][35][36].

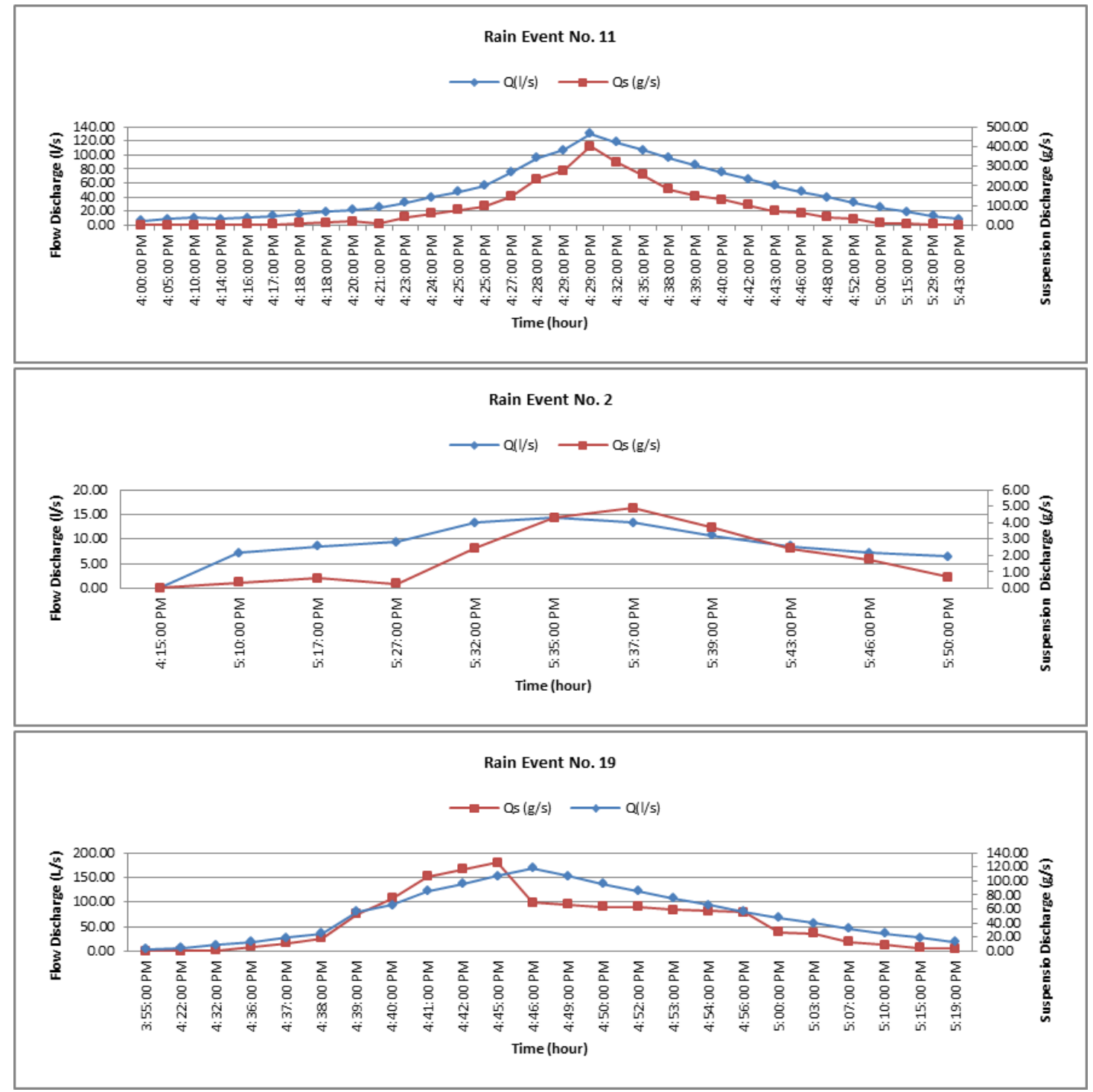

Figure 2. The types in the correspondence patterns of the peak suspension discharge and the peak flow discharge during the flows in each and several rain events (Rain event No. 11 in of the tQp=tQsp; Rain event No. 2 in of the tQp $>$ tQsp; and Rain even No 19, in of the tQp $<$ tQsp types) 
The response of runoff and suspension flow formation dynamics is identifiable by suspension hydrograph analysis. Hydrograph analysis illustrates the fluctuating movement of suspension flow following the dynamics of the rainfall characteristics [16][17][18][19]. Figure 2 shows that at the beginning of a rain event, the rain intensity and duration are still low, and, therefore, the flow discharge tends to be small. As the rain intensity and duration increase, the flow discharge and the peak suspension flow rise. Increased suspension flow discharge occurs because sediment production by raindrops and scouring (erosion) by water flows on the ground surface also increases. Increased suspension discharge at the same time as high flow discharge is caused by adequate suspension transport energy. At the recession stage, the rain intensity decreases and, therefore, the flow discharge declines. Decreased flow discharge reduces suspension production and sediment transport energy; accordingly, the suspension discharge becomes lower.

\subsection{The time lag of the suspension flow formation}

The time lag from rain events to the initial formation of suspension flow at the outlet varies widely (Table 2). It ranges between 4 and 55 minutes with an average of 17.7 minutes and a standard deviation of \pm 13 minutes. A high standard deviation indicates that the time lag from the beginning of the suspension flow formation and the rain events to the time at which the flows reach the outlet is highly diverse. In this research, the time lag of the initial formation of suspension flow is controlled by the response of the highly complex watershed condition, which includes the dynamics of the intensity and duration of the previous rain events, the channel's base flow, the intensity dynamics of the occurring rain event. The statistical analysis results from the correlation test showed that the causal factors with significant correlation coefficients were rain intensity (0.381) and runoff discharge (0.443), whose significance levels were 0.05 and 0.001 , respectively. The other factors, namely the dynamics of the time lag, the maximum intensity and duration of the previous rain events, and the base flow condition of the channel, had weak influence with insignificant correlation coefficients.

This study generally revealed different time lags from rain events to the initial formation of the suspension flow as a combination of the dynamics of the intensity and duration of previous rain events, the state of the channel's base flow, and the intensity dynamics of the occurring rainfall. At the beginning of the suspension flow formation, the rain intensity ranged from 1.2 to $97.2 \mathrm{~mm} /$ hour with an average of $15.6 \mathrm{~mm} /$ hour. The lowest rain intensity to initiate the formation of the suspension flow was 1.2 $\mathrm{mm} /$ hour with a time lag of 8-10 minutes. At the beginning of the suspension flow formation, the highest rain intensity was $97.2 \mathrm{~mm} /$ hour, with a time lag of 24 minutes. Low rain intensity with a shorter time lag is possible when the previous rainfall has high intensity and long duration. The base flow is present at the channel during the occurring rain event (events no. 15 and 17). In rain events no. 15 and 17, the lowest rain intensity $(1.2 \mathrm{~mm} /$ hour $)$ resulted in shorter time lags, i.e., 8 minutes and 10 minutes, respectively, when the previous rain events had high intensities, i.e., $39.6 \mathrm{~mm} /$ hour and $32.4 \mathrm{~mm} /$ hour, and long durations, i.e., 90 minutes and 120 minutes, respectively.

With high rainfall intensity of $22.14 \mathrm{~mm} / \mathrm{hours}$, the time lag was wide (slow) because the previous rainfall had low intensity and short duration and the base flow in the occurring rain event was low (event no. 33). In the event no. 33, the rain intensity was $97.2 \mathrm{~mm} /$ hour, but it had a long time lag, i.e., 24 minutes, because of the low intensity $(7.2 \mathrm{~mm} /$ hour $)$ and short duration (15 minutes) of the previous rainfall. The time lag of the initial formation of suspension flow also varied even when the rain fell with the same intensity. In several observations (events no. 9, 16, 34), the rain intensities were equal (2.4 $\mathrm{mm} /$ hour). However, the previous rain events had different intensities, i.e., $6 \mathrm{~mm} /$ hour, $4.8 \mathrm{~mm} /$ hour, and $97.2 \mathrm{~mm} /$ hour, and different durations, i.e., 256 minutes, 75 minutes, and 83 minutes, respectively, indicating different time lags, i.e., 10 minutes, 5 minutes, and 27 minutes, respectively. Events no. 15 and 17 also had equal rain intensities, i.e., $1.2 \mathrm{~mm} /$ hour. However, the rain events preceding them had different intensities, i.e., $39.6 \mathrm{~mm} /$ hour and $32.4 \mathrm{~mm} /$ hour, and different durations, i.e., 90 minutes and 120 minutes, which also resulted in different time lags, i.e., 8 minutes and 5 minutes. 
CIVENSE

Table 2. The dynamics of the aspects of previous rain events, occurring rain events, and the formation of suspension runoff

\begin{tabular}{|c|c|c|c|c|c|c|c|c|c|c|c|c|}
\hline No. & Rain events & & Previous ra & events & & Occurring $\mathrm{r}$ & n events & & & Suspen: & on flow eve & \\
\hline No. & Rain events & $\begin{array}{l}\text { Time lag to } \\
\text { previous } \\
\text { rain (hour) }\end{array}$ & $\begin{array}{l}\text { Max. rain } \\
\text { intensity } \\
(\mathrm{mm} / \text { hour })\end{array}$ & $\begin{array}{l}\text { Rain } \\
\text { depth } \\
(\mathrm{mm})\end{array}$ & $\begin{array}{c}\text { Rain } \\
\text { duration } \\
\text { (minute) }\end{array}$ & $\begin{array}{c}\text { Rain } \\
\text { intensity } \\
\text { at the } \\
\text { beginning } \\
\text { of } \\
\text { suspension } \\
\text { flow } \\
\text { (mm/hour) } \\
\end{array}$ & $\begin{array}{l}\text { Rain } \\
\text { depth at } \\
\text { the } \\
\text { initial } \\
\text { flow }\end{array}$ & $\begin{array}{l}\text { The time lag } \\
\text { between the } \\
\text { initial } \\
\text { formation of } \\
\text { suspension flow } \\
\text { and flow } \\
\text { reaching outlet } \\
\text { (minutes) }\end{array}$ & $\begin{array}{c}\text { Base } \\
\text { flow } \\
\text { condition } \\
(\mathrm{mm})\end{array}$ & $\begin{array}{l}\text { Suspension flow } \\
\text { events }\end{array}$ & $\begin{array}{c}\text { Runoff } \\
\text { discharge } \\
(\mathrm{L} / \mathrm{s})\end{array}$ & $\begin{array}{c}\text { Suspension } \\
\text { discharge } \\
(\mathrm{gram} / \mathrm{s})\end{array}$ \\
\hline 1 & 2 & 3 & 4 & 5 & 6 & 7 & 8 & 9 & 10 & 11 & 12 & 13 \\
\hline 1 & $16 / 02 / 2017$ & 21 & 1.2 & 2.1 & 15 & 2.6 & 4.2 & - & 35 & Not formed & - & - \\
\hline 2 & $17 / 02 / 2017$ & 24 & 3.6 & 5.1 & 15 & 1.2 & 0.3 & - & 35 & Not formed & - & - \\
\hline 3 & $18 / 02 / 2017$ & 18 & 1.2 & 0.3 & 15 & 15.6 & 9.6 & 10 & 32 & Formed & 11.75 & 0.08 \\
\hline 4 & $19 / 02 / 2017$ & 27 & 4.8 & 15.6 & 45 & 2.4 & 1.5 & - & 5 & Not formed & - & - \\
\hline 5 & $20 / 02 / 2017$ & 23 & 2.4 & 1.5 & 15 & 20.4 & 24.6 & 55 & 25 & Formed & 7.2 & 0.33 \\
\hline 6 & $21 / 02 / 2017(1)$ & 14 & 20.4 & 24.6 & 95 & 10.8 & 6 & 10 & 22 & Formed & 7.2 & 0.45 \\
\hline 7 & $21 / 02 / 2017$ (2) & 10 & 10.8 & 6 & 30 & 16.6 & 18.3 & 20 & 25 & Formed & 7.2 & 0.04 \\
\hline 8 & $22 / 02 / 2017$ & 24 & 16.6 & 18.3 & 120 & 6 & 14.7 & 37 & 25 & Formed & 7.2 & 0.19 \\
\hline 9 & $23 / 02 / 2017$ & 11 & 6 & 14.7 & 256 & 2.4 & 1.5 & 10 & 25 & Formed & 7.2 & 0.06 \\
\hline 10 & $24 / 02 / 2017$ & 33 & 2.4 & 1.5 & 30 & 4.8 & 4.5 & - & 19 & Not formed & - & - \\
\hline 11 & $25 / 02 / 2017$ & 16 & 9.6 & 8.7 & 135 & 14.4 & 24.9 & 28 & 22 & Formed & 7.2 & 0.04 \\
\hline 12 & $26 / 02 / 2017$ & 18 & 14.4 & 24.9 & 225 & 4.8 & 4.5 & 12 & 05 & Not formed & - & - \\
\hline 13 & $27 / 02 / 2017$ & 20 & 4.8 & 4.5 & 90 & 7.2 & 4.8 & 8 & 25 & Formed & 7.2 & 0.11 \\
\hline 14 & $28 / 02 / 2017$ & 13 & 7.2 & 4.8 & 60 & 6 & 1.5 & 14 & 25 & Formed & 8.48 & 0.52 \\
\hline 15 & $01 / 03 / 2017(1)$ & 15 & 39.6 & 25.5 & 90 & 1.2 & 0.3 & 10 & 25 & Formed & 8.48 & 1.32 \\
\hline 16 & $01 / 03 / 2017(2)$ & 2 & 4.8 & 6 & 75 & 2.4 & 0.6 & 5 & 25 & Formed & 8.48 & 1.87 \\
\hline 17 & $02 / 03 / 2017$ & 20 & 32.4 & 51.3 & 120 & 1.2 & 1.2 & 8 & 30 & Formed & 8.48 & 0.99 \\
\hline 18 & 04/03/2017 & 40 & 33.6 & 36 & 105 & 2.4 & 1.8 & - & 25 & Not formed & - & - \\
\hline 19 & 05/03/2017 & 28 & 2.4 & 2.4 & 45 & 2.7 & 10.8 & 4 & 35 & Formed & 13.27 & 2.08 \\
\hline 20 & 06/03/2017 & 24 & 21.6 & 9.9 & 60 & 28.4 & 1.4 & - & 01 & Not formed & - & - \\
\hline 21 & 07/03/2017 & 23 & 26.4 & 6.9 & 15 & 49.2 & 12.3 & 14 & 30 & Formed & 10.78 & 1.27 \\
\hline 22 & $14 / 03 / 2017(1)$ & 72 & 12 & 4.8 & 15 & 6 & 1.5 & - & 5 & Not formed & - & - \\
\hline
\end{tabular}

Continued to the next page 
CIVENSE

Table 2 (continued)

\begin{tabular}{|c|c|c|c|c|c|c|c|c|c|c|c|c|}
\hline 1 & 2 & 3 & 4 & 5 & 6 & 7 & 8 & 9 & 10 & 11 & 12 & 13 \\
\hline 23 & $14 / 03 / 2017(2)$ & 2 & 6 & 2.1 & 15 & 2.4 & 1.5 & - & 5 & Not formed & - & - \\
\hline 24 & $14 / 03 / 2017$ (3) & 1 & 9.6 & 12.9 & 60 & 2.4 & 2.4 & - & 5 & Not formed & - & - \\
\hline 25 & $17 / 03 / 2017$ & 48 & 28 & 21.3 & 75 & 2.4 & 2.2 & - & 32 & Not formed & - & - \\
\hline 26 & $18 / 03 / 2017$ & 17 & 4.8 & 2.4 & 90 & 28.8 & 7.2 & 39 & - & Formed & 1.58 & 1.41 \\
\hline 27 & $20 / 03 / 2017$ & 21 & 40.8 & 57 & 150 & 4.8 & 1.8 & - & - & Not formed & - & - \\
\hline 28 & $24 / 03 / 2017$ & 72 & 18 & 6.9 & 45 & 2.4 & 1.5 & - & 22 & Not formed & - & - \\
\hline 29 & $25 / 03 / 2017$ & 16 & 2.4 & 2.4 & 30 & 5.1 & 20.4 & 10 & 15 & Formed & 4.54 & 0.54 \\
\hline 30 & 26/03/2017 & 11 & 30 & 42 & 120 & 9.6 & 38.4 & 14 & 15 & Formed & 4.54 & 0.94 \\
\hline 31 & 04/04/2017 (1) & 15 & 2.4 & 19.8 & 75 & 8.4 & 2.4 & - & - & Not formed & - & - \\
\hline 32 & $04 / 04 / 2017(2)$ & 8 & 8.4 & 3.1 & 15 & 7.2 & 1.8 & - & - & Not formed & - & - \\
\hline 33 & $05 / 04 / 2017$ & 19 & 7.2 & 5.7 & 15 & 97.2 & 24.3 & 24 & 15 & Formed & 18.83 & 11.13 \\
\hline 34 & $06 / 04 / 2017$ & 19 & 97.2 & 74.4 & 83 & 2.4 & 0.6 & 27 & 15 & Formed & 4.54 & 0.38 \\
\hline 35 & $17 / 04 / 2017$ & 120 & 2.4 & 1.2 & 15 & 16.8 & 5.4 & - & - & Not formed & - & - \\
\hline \multirow[t]{5}{*}{36} & $18 / 04 / 2017$ & 17 & 16.8 & 5.4 & 15 & 22.8 & 5.7 & 12 & - & Formed & 0.55 & 0.02 \\
\hline & Mean & 24.5 & 15.3 & 14.8 & 68.7 & 11.7 & 7.4 & 17.7 & 21 & & 7.7 & 1.2 \\
\hline & Max. & 120 & 97.2 & 74.4 & 256 & 97.2 & 38.4 & 55 & 35 & & 18.83 & 11.13 \\
\hline & Min. & 1 & 1.2 & 0.3 & 15 & 1.2 & 0.3 & 4 & 01 & & 0.55 & 0.02 \\
\hline & Sdev. & 22.6 & 18.2 & 17.6 & 58.6 & 17.9 & 9.1 & 13.0 & 10 & & 4.0 & 2.4 \\
\hline
\end{tabular}

Source: Field data processing (2017) 
This study argued that the time lag of the initial formation of the suspension flow was influenced dynamically by a combination of factors, including the intensity and duration of previous rain events, the intensity of the occurring rainfall, and the base flow of the channel. The combination of these factors significantly controls the initial formation of suspension flow and is supported by the concept of flow formation mechanism. The flow formation mechanism explains that a flow forms when the soil surface receives rain input and absorbs water vertically into the soils by infiltration and percolation. As well as when these processes affect the initial humidity status of the soil surface [36], make the soil watersaturated, and form runoff on the soil surface in the event of excess rainfall [24][22][35].

This study provides the time lag between the initial formation of suspension flow and rain event, which tends to be longer (17.7 minutes) in a volcanic watershed with super thick soils and land cover in the form of agroforestry. The super thick soil in the volcanic watershed has a high clay content $(>50 \%)$, and it can bind and store more water; therefore, suspension flow takes a longer time to form [40]. The plant root density under the agroforestry practices is beneficial in initiating the formation of fractures and secondary soil pores to increase infiltration and soil water storage capacity. Soil conditions with high infiltration and soil water storage capacity can slow down the process of runoff (flow) formation that carries suspension on the surface, as previously reported by [16][37]. According to [38], soil permeability reflects soil infiltration capacity. The permeability of the super thick soils in the study area ranged from $0.0259 \mathrm{~cm} /$ hour to $80.0759 \mathrm{~cm} /$ hour with an average of $0.4492 \mathrm{~cm} /$ hour (slow). Slow soil permeability triggers a faster formation of suspension flow on the soil surface. In line with [39], the combination of initial water content and infiltration affects the initial infiltration rate. When the need to reach the initial soil moisture content is higher, the lower the initial infiltration rate. Suspension flow forms when rain input exceeds infiltration capacity; in other words, the formation of suspension flow is highly dependent on the fulfillment of infiltration capacity.

The time lag between the suspension flow formation and rain event in this research was wide (17.7 minutes). The wide time lag proves that the vegetation roots in agroforestry land use, which create fractures and soil pores, can increase water absorption in infiltration and soil water storage capacity. The super thick soil condition with high infiltration capacity and large soil water storage in the volcanic watershed can store more water and slow the formation of suspension flow.

\subsection{The characteristics of the grain size of the suspension}

The results presented in Table 1 show that the suspension level at the peak suspension flow discharge has a concentration ranging from $0.0016 \mathrm{~g} / \mathrm{L}$ to $4.71 \mathrm{~g} / \mathrm{L}$ with an average of $1.03 \mathrm{~g} / \mathrm{L}$. The most negligible suspension concentration was $0.0016 \mathrm{~g} / \mathrm{L}$, which occurred in the event no. 2 with a peak runoff discharge of $8.48 \mathrm{~L} / \mathrm{s}$. The highest suspension concentration was $4.71 \mathrm{~g} / \mathrm{L}$, which happened in rain event no. 36 with a peak runoff discharge of $21.26 \mathrm{~L} / \mathrm{s}$. In general, the study shows that the peak flow discharge influences the suspension level, i.e., low peak flow discharge has a small suspension concentration. In contrast, high peak flow discharge has a large suspension concentration. The situation in which peak flow discharge affects suspension content is in line with the results of previous studies, including the correlation between suspension's grain size and flow conditions, namely flow discharge and rate [41][42].

In the study area, the grain size of the suspension in the suspension flow is dominated by clay fraction. The dominant clay fraction corresponds to the clay fraction found in the surface soil layer in the volcanic watershed area. The grain size of the suspension was grouped according to the percentages of the clay, silt, and sand fractions whose granular scales are $<0.002 \mathrm{~mm}, 0.002-0.02 \mathrm{~mm}$, and $0.02-2 \mathrm{~mm}$, respectively. The grain size of the suspension at the rising stage had the following mean percentages: $2 \%$ sand, $26 \%$ silt, and $73 \%$ clay. At the recession stage, the grain size of the suspension was composed of the following mean percentages: $3 \%$ sand, $28 \%$ silt, and $69 \%$ clay. The fraction of the surface soil layer consisted of the following mean percentages: $2 \%$ sand, $26 \%$ silt, and $73 \%$ clay. During the flow events, the clay-sized suspension fraction showed a decrease from $73 \%$ at the rising stage to $69 \%$ at the falling phase. 
Meanwhile, the sand-sized suspension increased from $2 \%$ to $3 \%$, and the silt-sized suspension also increased from $26 \%$ to $29 \%$. The increases in the sand and silt-sized fractions and the decline in claysized grain in the suspension during the flow events not only indicate different levels of transportability between the sand, silt, and clay-sized suspension but also demonstrate an increase in the transportation of sediment originating in the channel during the flow events. Clay fractions are mostly transported in the rising phase when flow discharge is low because clay has a very small and delicate size that is more easily suspended and transported. Meanwhile, the silt and sand-sized fractions are mostly carried in the recession phase when flow discharge accumulates and becomes larger. Silt and sand are larger and coarser so that their disaggregation and transportation processes require stronger flow discharge energy and more prolonged time [43][44][45]. The increased silt and sand contents in the suspension during the flow events indicate that the increased flow discharge can trigger intensive soil disaggregation and sediment transport. This research argues that significant accumulation of flow discharge prompts intensive suspension transport and flow in a volcanic watershed area, which occurs not only on soils with clay content but also on sand and silt fractions.

\section{Conclusions}

During the rain events, the dynamics of the suspension flow showed correspondence patterns between flow discharge and suspension discharge in the rising and falling phases. At the peak condition, there are three relationship patterns between the peak flow discharge and the peak suspension discharge, namely (1) the peak flow discharge corresponds to the peak suspension discharge, (2) the peak flow discharge precedes the peak suspension discharge, and (3) the peak flow discharge occurs after the peak suspension discharge.

The time lag from rain events to the formation of suspension flow ranges from 4 minutes to 55 minutes, with an average of 17.7 minutes. The wide time lag proves that the vegetation roots in agroforestry land use, which create fractures and soil pores, can increase water absorption in infiltration and soil water storage capacity. The peak suspension content varies between $0.0016 \mathrm{~g} / \mathrm{L}$ and $4.71 \mathrm{~g} / \mathrm{L}$ with an average of $1.03 \mathrm{~g} / \mathrm{L}$. The grain size of the suspension is mainly from clay fraction with a range of $71 \%$ to $76 \%$, and the average is $73 \%$ in the rising phase. Furthermore, the recession phase ranges between $68 \%$ and $71 \%$, with an average of $69 \%$. Silt and sand fractions in the suspension are averagely $26 \%$ and $2 \%$ in the rising phase and $28 \%$ and $3 \%$ at the recession phase.

\section{Acknowledgments}

The authors would like to express their gratitude to all parties, especially the Transbulent Team for the togetherness during data collection in the field until the realization of this publication material. The authors would also like to thank LPDP (Lembaga Pengelola Dana Pendidikan-Indonesia Endowment Fund for Education) for the financial support during the course of this Education Program.

\section{References}

[1] Badan Geologi Indonesia, 2011, Data Dasar Gunung Api Indonesia, Edisi ke-2, Kementrian Energi dan Sumber Daya Mineral, Bandung.

[2] Asriningrum, W., Noviar, H., \& Suwarsono. 2004. Pengembangan Metode Zonasi Daerah Bahaya Letusan Gunungapi Studi Kasus Gunung Merapi. Jurnal Penginderaan Jauh dan Pengolahan Data Citra Digital, 1(1), pp.66-75.

[3] Nandini, R \& Narendra, B.H. 2012. Karakteristik Lahan Kritis Bekas Letusan Gunung Batur di Kabupaten Bangli, Bali. Penelitian Hutan dan Konservasi Alam, 9(3), pp.199-211.

[4] Bachri, S., Utaya, S., Nurdiansyah, F.D., Nurjanah, A.E., Tyas, LWN., Purnama, D.S., \& Adillah, A.A. 2017. Analisis dan Optimalisasi Potensi Lahan Pertanian sebagai Kajian Dampak Positif Erupsi Gunungapi Kelud 2014. Majalah Geografi Indonesia, 1790.

[5] Kimmins, J.P., Rempel, R.S., Welham, C.V.J., Seely, B., \& Van Rees, K.C.J. 2007. Biophysical sustainability, process-based monitoring and forest ecosystem management decision support systems. The Forestry Chronicle, 83(4), pp.502-514. 
[6] Verstraeten, G., Prosser, I.P., \& Fogarty, P., 2007. Predicting the spatial patterns of hillslope sediment delivery to river channels in the Murrumbidgee catchment, Australia. Journal of Hydrology, 334(3-4), pp.440-454.

[7] Kironoto, B.A., 2008. Konsentrasi Sedimen Suspensi Rata-Rata Kedalaman Berdasarkan Pengukuran 1, 2, dan 3 Titik pada Aliran Seragam Saluran Terbuka. Dinamika Teknik Sipil, 8(1), pp.59-71.

[8] Panagos, P, Borrelli, P, Poesen, J, Ballabio, Lugato, E., Meusburger, K., Montanarella, L., \& Allewl, C. 2015. The new assessment of soil loss by water erosion in Europe. Environmental Science \& Policy, 54, 438-447. http://doi.org/10.1016/j.envsci.2015.08.012.

[9] Suripin, 2002. Pelestarian Sumber Daya Tanah dan Air. Andi Offset. Yogyakarta.

[10] Merritt, W.S., Lecther, R.A., \& Jakeman, AJ. 2003. A review of erosion and sediment transport model. Environment Model Software, 18: 761-799.

[11] Ma'wa, J., \& Andawayanti, U. 2009. Studi Pendugaan Sisa Usia Guna Waduk Sengguruh Dengan Pendekatan Erosi dan Sedimentasi.

[12] Parsons, A.J., \& Wainwright, J. 2000. Modeling Surface Runoff. In Schmidt, J. (ed). Soil Erosion, Application of Physically Based Models. Germany: Springer.

[13] Handayani, Y.L., Jayadi, R., \& Triatmojo, B., 2005. Optimasi Tata Guna Lahan dan Penerapan Rekayasa Teknik dalam Analisa Banjir di Daerah Aliran Sungai: Studi Kasus Daerah Aliran Sungai Ciliwung Hulu Di Bendung Katulampa. Manusia dan Lingkungan, 12(2), pp.53-61.

[14] Oktarina, N.R. 2005. Analisis Hidrograf Limpasan Akibat Variasi Intensitas Hujan dan Kemiringan Lahan (Kajian Laboratorium dengan Simulator Hujan). Jurnal Teknik Sipil dan Lingkungan. Vol. 3, No. 1, Maret 2015.

[15] Walker, S., \& Mostaghimi, S. 2009. Watershed-Based Systems. In Moore, K.M. (ed). The Sciences and Art of Adaptive Management Innovating for Sustainable Agriculture and Natural Resource Management. Ankeny, Iowa: Soil and Water Conservation Society.

[16] Handayani, W., \& Indrajaya, Y. 2011. Analisis Hubungan Curah Hujan dan Debit Sub Sub DAS Ngatabaru, Sulawesi Tengah. Jurnal Penelitian Hutan dan Koservasi Alam, Vol. 8, No.2, pp.143-153.

[17] Bisantino, T., Bingner, R., Chouaib, W., Gentile, F., \& Liuzzi, G.T. 2013. Estimation of runoff, peak discharge and sediment load at the event scale in a medium-size Mediterranean watershed using the annAGNPS model. Land Degradation \& Development. Available at: 10.1002/ldr.2213.

[18] Miller, J.R. Mackin, G., \& Miller, S.M.O. 2015. Application of Geochemical Tracers to Fluvial Sediment, London: Springer.

[19] Gao, P., Deng, J.,Chai, X., Mu, X., Zhao, G., Shao, H., \& Sun, W. 2017. Science of the Total Environment Dynamic sediment discharge in the Hekou - Longmen region of Yellow River and soil and water conservation implications. Science of the Total Environment, The, 578, pp.56-66. Available at: http://dx.doi.org/10.1016/j.scitotenv.2016.06.128.

[20] Hergarten, St., Paul, G., \& Neugebauer, H.J. 2000. Modeling Surface Runoff. In Schmidt, J. (ed). Soil Erosion, Application of Physically Based Models. Germany: Springer.

[21] Poesen, J., Nachtergaele, J., Verstraeten, G., \& Valentina, C. 2003. Gully erosion and environmental change: importance and research needs. Catena, 50, 91-133. http://dx.doi.org/10.1016/S0341-8162(02)00143-1.

[22] Arsyad, S. 2006. Konservasi Tanah dan Air. Bandung: IPB Press.

[23] Fryirs, K.A. \& Brierley, G.J. 2013. Geomorphic Analysis of River Systems 1st ed., A John Wiley \& Sons, Ltd., Publication.

[24] Soemarto, C.D. 1999. Hidrologi Teknik. Pusat Pendidikan Manajemen dan Teknologi Terapan. Malang.

[25] Dariah, A., Subagyo, H., Tafakresnanto, S., \& Marwanto, S. 2003. Kepekaan Tanah terhadap Erosi. Jurnal Akta Agrosia Vol. 8, No.2.

[26] Morgan, R.P.C. 2005. Soil Erosion and Conservation: Third Edition. USA; Blackwell. 
[27] Nicótina, L. et al. 2011. Hydrologic controls on equilibrium soil depths. Water Resources Research, 47(4), pp.1-11.

[28] Rusdi, Alibasyah, M. R., \& Abubakar, K. 2013. Evaluasi Degradasi Lahan diakibatkan Erosi pada Areal Pertanian di Kecamatan Lembah Seulawah Kabupaten Aceh Besar. Jurnal Konservasi Sumber Daya Lahan. Pascasarjana Universitas Syiah Kuala, Vol. 1, No. 1, Mei 2013, 1(1), 24-39.

[29] Sartohadi, J. 2013. Genesis Tanah Supertebal dan Kaitannya dengan Longsor dalam di Hulu DAS Bogowonto Jawa Tengah. Hibah Penelitian Dosen. LPPM UGM Yogyakarta.

[30] Wulandari, D.A., Suripin, and Syafrudin. 2014. Evaluasi Penggunaan Lengkung Laju DebitSedimen (Sediment-Discharge Rating Curve) Untuk Memprediksi Sedimen Layang. http://eprints.undip.ac.id/4670/DYA.

[31] Herschy, R.W., 2009. Streamflow Measurement Third edit. T. \& Francis, ed., 2 Park Square, Milton Park, Abingdon, Oxon OX14 4RN.

[32] Soewarno. 1991. Hidrologi Pengukuran dan Pengukuran Daerah Aliran Sungai. Bandung: Nova.

[33] Arianti, F.D., Suratman, Martono, E., \& Suprayogi, S. 2012. Dampak Pengelolaan Lahan Pertanian terhadap Hasil Sedimen di Daerah Aliran Sungai Galeh Kabupaten Semarang. Jurnal Manusia dan Lingkungan. Vol. 19, No. 3. Available at: http://ilib.ugm.ac.id/jurnal/detail.php?dataId=12641 [Accessed September 19, 2015].

[34] Maulana, R.A., Lubis, K.S., \& Marbun, P. 2014. Uji Korelasi antara Debit Aliran Sungai dan Konsentrasi Sedimen Melayang pada Muara Sub DAS Padang di Kota Tebing Tinggi. Jurnal Online Agroekoteknologi, 2(2337), pp.1518-1528.

[35] Triatmodjo, B. 2013. Hidrologi Terapan. Cetakan ke-3, Beta Offset, Yogyakarta.

[36] Neno, A.K. et al. 2016. Hubungan Debit Air dan Tinggi Muka Air di Sungai Lambagu Kecamatan Tawaeli Kota Palu. Warta Rimba,Vol. 4 Nomor 2 Desember 2016, 4, pp.1-8.

[36] Wang, J., Huang, J., Wu, P., Zhao, X., Gao, X., Dumlao, M., Si, B.C. 2015. Effects of soil managements on surface runoff and soil water content in jujube orchard under simulated rainfalls. $\quad$ Catena, 135, pp.193-201. Available at: http://www.sciencedirect.com/science/article/pii/S0341816215300795 [Accessed September $16,2015]$.

[37] Gumiere, S.J., Bailly, J.S., Cheviron, B., Raclot, D., Bissonnais, Y.L., \& Rousseau, A.N. 2015. Evaluating the Impact of the Spatial Distribution of Land Management Practices on Water Erosion: Case Study of a Mediterranean Catchment. J. Hydrol. Eng., 2015, 20(6): C5014004, 20(2004), pp.1-10.

[38] Haridjadja O, Murtilaksono, K., Sudarmo, Rahman, L.M. 1990. Hidrologi Pertanian. Jurusan Tanah. Fakultas Pertanian. Bogor (ID): Institut Pertanian Bogor.

[39] Asdak, C. 2002. Hidrologi dan Pengelolaan Daerah Aliran Sungai. Yogyakarta: Gadjah Mada University Press.

[40] Mbaya, L.A., Ayuba, H.K., \& Abdullahi, J. 2012. An assessment of gully erosion in Gombe Town, Gombe State. Journal of Geography and Geology, 4(3), pp.110-122.

[41] Steegen, A., Govers, G., Nachtergaele, J., Takken, I., \& Poesen, J. 2000. Sediment export by water from an agricultural catchment in the Loam Belt of central Belgium. Geomorphology, 33 , pp.25-36.

[42] Tillinghast, E.D., Hunt, W.F., \& Jennings, G.D., 2011. Stormwater control measure (SCM) design standards to limit stream erosion for Piedmont North Carolina. Journal of Hydrology, 411(34), pp.185-196. Available at: http://dx.doi.org/10.1016/j.jhydrol.2011.09.027.

[43] Castillo, V.M., Mosch, W.M., García, C.C., Barberá, G.G., Cano, J.A.N., \& Bermúdez, F.L. 2007. Effectiveness and geomorphological impacts of check dams for soil erosion control in a semiarid Mediterranean catchment: El Cárcavo (Murcia, Spain). Catena, 70(3), pp.416-427. Available at: http://www.sciencedirect.com/science/article/pii/S0341816206002438 [Accessed on September 16, 2015]. 
[44] Haregeweyn, N., Melesse, B., Tsunekawa, A., Tsubo, M., Meshesha, D., \& Balana, B.B. 2012. Reservoir sedimentation and its mitigating strategies: A case study of Angereb reservoir (NW Ethiopia). Journal of Soils and Sediments, 12(2), pp.291-305.

[45] Nugroho, S.H. dan Basit, A., 2014. Sebaran Sedimen Berdasarkan Analisis Ukuran Butir di Teluk Weda, Maluku Utara. Jurnal Ilmu dan Teknologi Kelautan Tropis, 6(1), pp.229-240. 